\title{
ON POHLIA SAPROPHILA (MIELICHHOFERIACEAE, BRYOPHYTA)
}

\section{O POHLIA SAPROPHILA (MIELICHHOFERIACEAE, BRYOPHYTA)}

\author{
IRINA V. CZERNYADJEVA ${ }^{1}$, OXANA I. KUZNETSOVA ${ }^{2} \&$ MiCHAEL S. IGNATOV ${ }^{2.3}$ \\ ИРИНА В. ЧЕРНЯДЬЕВА ${ }^{1}$, ОКСАНА И. КУЗНЕЦОВА ${ }^{2}$, МИХАИЛ С. ИГНАТОВ ${ }^{2,3}$
}

Abstract

\begin{abstract}
The status and distribution of Pohlia saprophila (Müll. Hal.) Broth. remained vague, as this species was not specially studied. Being described from the Central China, Gansu Province, it was treated as doubtful in the last edition of the Moss Flora of China. This species is closely related to P. elongata, and its distinction from it in dioicous sexual condition could be considered ambiguus, as dioicous plants occasionally occur in some populations of P. elongata as well. However, dioicous sexuality in Pohlia saprophila is stable and consistent with very dense growth of plants due to numerous rhizoids, and also is well supported by ITS sequence data. In addition to China, Pohlia saprophylla occurs in Mongolia, Kazakhstan, Kyrgyzstan, South Siberia (Altai and Transbaikalia) and extends eastward to Kamchatka. Another species, which was described as dioicous in this groups, P. viridis Lindb. \& Arnell, is synonymized with $P$. elongata.
\end{abstract}

Резюме

Таксономический статус и распространение Pohlia saprophila (Müll. Hal.) Broth. оставались до последнего времени не вполне понятными, поскольку специального изучения его не предпринималось. Описанный из провинции Ганьсу, Центральный Китай, вид в последнем издании Флоры мхов Китая был отнесет к сомнительным. Pohlia saprophila является близкородственным видом к P. elongata, и ее отличия, касающиеся, в первую очередь, двудомности могли расцениваться как недостаточные для выделения вида, тем более что двудомные и многодомные растения изредка встречаются и у самой P. elongata. Однако двудомность у Pohlia saprophila является константным признаком, и особенности ее роста в обширных, густых, сильно войлочных дерновинках указывает на самостоятельность этого вида, что поддерживается и данными анализа ITS последовательностей ДНК. Помимо Китая, вид встречается также в Монголии, Киргизии, Казахстане, а в России выявлен в Южной Сибири (Алтай и Забайкалье) и на Камчатке. Другой вид из группы P. elongata, P. viridis Lindb. \& Arnell, описанный как двудомный, отнесен в синонимы к P. elongata.

KEYWORDS: mosses, Pohlia saprophila, new records, Russia

\section{INTRODUCTION}

Pohlia saprophila (Müll. Hal.) Broth. was originally described (as Bryum) from Gansu (Kansu, Gangsu) Province of China from collections of Potatin (Müller, 1896). Subsequently it was transferred to Pohlia by Brotherus (1903). Pohlia saprophila was included in the Checklist of mosses of China (Redfearn et al., 1996), however, in the Moss flora of China it was referred to doubtful species (Zhang et al., 2007).

The original description of $P$. saprophila was very short (Müller, 1896). Savicz-Lyubitskaya \& Smirnova (1970) published their own illustrations of this species and its full-length description, in Russian. According to their description, the species is characterized by dioicous sexual condition, lanceolate leaves with recurved margins, long laminal cells, narrow, inclined capsules with endostome with rather long cilia, and growth on rotten logs in mountain forests of Cental Asia.

The shape of capsules of $P$. saprophila is very similar to that of $P$. elongata Hedw., and most other characters also fit the latter species as well, especially because $P$. elongata is a very polymorphic and, being typically paroicous, is occasionally dioicous (Shaw, 2014). Therefore, the doubts in the clear distinction of plants with P. saprophila-phenotype from $P$. elongata are quite natural.

This our preliminary opinion, however, was overturned by observations in the field. The abundant rhizoid tomentum makes tufts of $P$. saprophila very dense, and it often grows in expanded mats. Sometimes $P$. saprophila covers a considerable parts of fallen logs, not in a way common to $P$. nutans (Hedw.) Lindb., which forms tufts, but not so extensive; moreover, it is not similar to

\footnotetext{
1 - Komarov' Botanical Institute of Russian Academy of Sciences, Prof. Popov Str., 2, St. Petersburg, 197376 Russia; e-mail: irinamosses@yandex.ru

2 - Tsitsin' Main Botanical Garden of Russian Academy of Sciences, Botanicheskaya 4, Moscow 127276 Russia

3 - Lomonosov' Moscow State University, Faculty of Biology, Moscow 119991 Russia; e-mails: misha_ignatov@list.ru
} 
P. elongata in growth pattern, as the latter species grows almost always on soil or rocks, in a rather loose tufts. The sexual condition of such plants is always dioicous, with both sexes represented in most populations.

Original test with ITS sequences revealed almost complete identity of Siberian specimen of Pohlia saprophila with two accessions of $P$. crudoides (Sull. \& Lesq.) Broth. from GenBank, based on Chinese collections. To understand the case, we expanded the set of specimens, including few putatively related species.

\section{MATERIAL AND METHODS}

Species selection, in addition to $P$. saprophila, which was sampled from three distant areas, includes $P$. elongata var. elongata, P. elongata var. greenii (Brid.) A.J. Shaw, P. longicollis (Hedw.) Lindb., P. cruda (Hedw.) Lindb., P. crudoides, P. obtusifolia (Vill. ex Brid.) L.F. Koch, P. nutans (different phenotypes), and P. drummondii (Müll. Hal.) A.L. Andrews.

DNA extraction and amplification were done according to the laboratory protocols described in Gardiner et al. (2005). The newly obtained data for 24 specimens were supplemented with five sequences available in GenBank. Voucher specimens and GenBank accession list is in Appendix 1 (supplementary materials). Sequences were aligned using BioEdit (Hall, 1999). Bayesian analysis was conducted in MrBayes 3.1.2 (Ronquist et al., 2012) using the GTR $+\mathrm{G}$ model, for 10,000,000 generations with sampling every 1000 generations. Three simultaneous runs were used. The first $25 \%$ of sampled trees were discarded for the burn-in. Mamimum parsimony analysis was completed with Nona (Goloboff, 1994) within the Winclada shell (Nixon, 1999), with bootstrap calculation with 2000 replications.

\section{RESULTS}

ITS region was found very variable in the studied group of Pohlia, so even a simple inclusion of a sequenced specimen in alignment provided a sufficient evidence of its specimen identity for most taxa (Fig. 1).

The identical sequences of all samples of $P$. saprophila from populations at $5000 \mathrm{~km}$ one from another confirm the separate status of this species.

Bayesian and maximum parsimony analyses were rooted on Pohlia longicollis, a taxon maximally dissimilar to other studied species, as it is seen from the alignment. An attempt to include a more distant species of the same genus, Pohlia drummondii, has failed, as the sequence is so different that it is almost impossible to align.

Bayesian analysis (Fig. 2) found the clade of P. cruda $(\mathrm{PP}=1 / \mathrm{BS}=100)$ to be sister to the clade of all other species. The latter clade $(\mathrm{PP}=1 / \mathrm{BS}=0.96)$ includes $P$. crudoides $(\mathrm{PP}=0.95)$, and another clade $(\mathrm{PP}=1 / \mathrm{BS}=84)$, which is subdivided into two terminal clades. One of these terminal clades $(\mathrm{PP}=1 / \mathrm{BS}=99)$ includes $P$. nutans $+P$. obtusifolia, another one $(\mathrm{PP}=1 / \mathrm{BS}=98)$ accomodates $P$. elongata and $P$. saprophila. The first clade is subdivided into $P$. obtusifolia $(\mathrm{PP}=0.84 / \mathrm{BS}=68)$ and $P$. nutans $(\mathrm{PP}=1 / \mathrm{BS}=96)$.
The second terminal clade includes $P$. elogata var. elongata-clade $(\mathrm{PP}=1 / \mathrm{BS}=100)$, sister to clade $(\mathrm{PP}=1$ / $\mathrm{BS}=94)$ with two subclades: P. elongata var. greenii $(\mathrm{PP}=1 / \mathrm{BS}=99)$ and $P$. saprophila $(\mathrm{PP}=1 / \mathrm{BS}=99)$. The latter includes two sequences from one Chinese specimen kept in GenBank under $P$. crudoides name, but their identity with $P$. saprophila and difference from $P$. crudoides is obvious. Most probably, this misnaming was caused by underestimation of $P$. sarphophila and by similarity between these two species in having narrow lanceolate leaves with recurved margins and only slightly inclined narrowly cylindrical capsules.

Interestingly, P. saprophila appeared to be most closely related to $P$. elongata var. greenii, despite the latter is more distinct from $P$. saprophila than $P$. elongata var. elongata, especially in capsule shape: in P. elongata var. greenii it is short and more similar to that of $P$. nutans than of $P$. elongata. The 'typical' phenotype of the latter species with narrowly cylindrical capsules was sampled from four localities situated at considerable distance (ca. $2000 \mathrm{~km}$ ) from each other, and their sequences were found to be almost identical. At the same time, two samples of $P$. elongata var. greenii considerably differ from each other, suggesting a complex situation in this group. Certainly, an expanded sampling of $P$. elongata var. greenii may reveal either more taxa in this group and/or phylogeographically interesting patterns.

Although $P$. nutans was not in the main focus of the paper, we selected few medium-sized forest phenotypes and some slender, high mountain, $P$. drummondii-like phenotypes. No stable genetic differentiation was noticed between them.

\section{TAXONOMY}

Pohlia saprophila (Müll. Hal.) Broth., Nat. Pflanzenfam. 1(3): 548. 1903. - Bryum saprophilum Müll. Hal., Nuovo Giorn. Bot. Ital., n.s. 3: 97. 1896. Fig. 3.

Lectotype (selected here): China borealis, province Kansu occidental, vallin flum. Baga-Rhudonsug, 5.V.1885, Potanin (LE!).

Isolectotype: MO: http://www.tropicos.org/Image/ 100147243. Numerous syntypes with other collection dates were seen in LE, H, S, BM.

Description. Plants robust, in silky yellowish green to light green, very dense tufts with brown or rusty tomentum. Stems 0.5-1.5(-4) cm long, densely foliate, generally simple, near the base sometimes forking and darkbrown, red to blackish, with dense rhizoids. Leaves appressed when dry, erecto-patent when moist, often more or less twisted around the stem, $1.3-2.4(-2.8) \times 0.3-0.5$ $\mathrm{mm}$, ovate-lanceolate to linear-lanceolate, gradually tapering to acute apex; margins narrowly recurved, denticulate at apex; costa stout, ending shortly below apex, 60-120 $\mu \mathrm{m}$ wide at base, 1/6-1/4 of leaf width at base; laminal cells thick-walled, rectangular to linear, 35-75 $(-100) \times 7-13 \mu \mathrm{m}$, at base shorter and wider and often pinkish. Brood branches often present in leaf axils in 


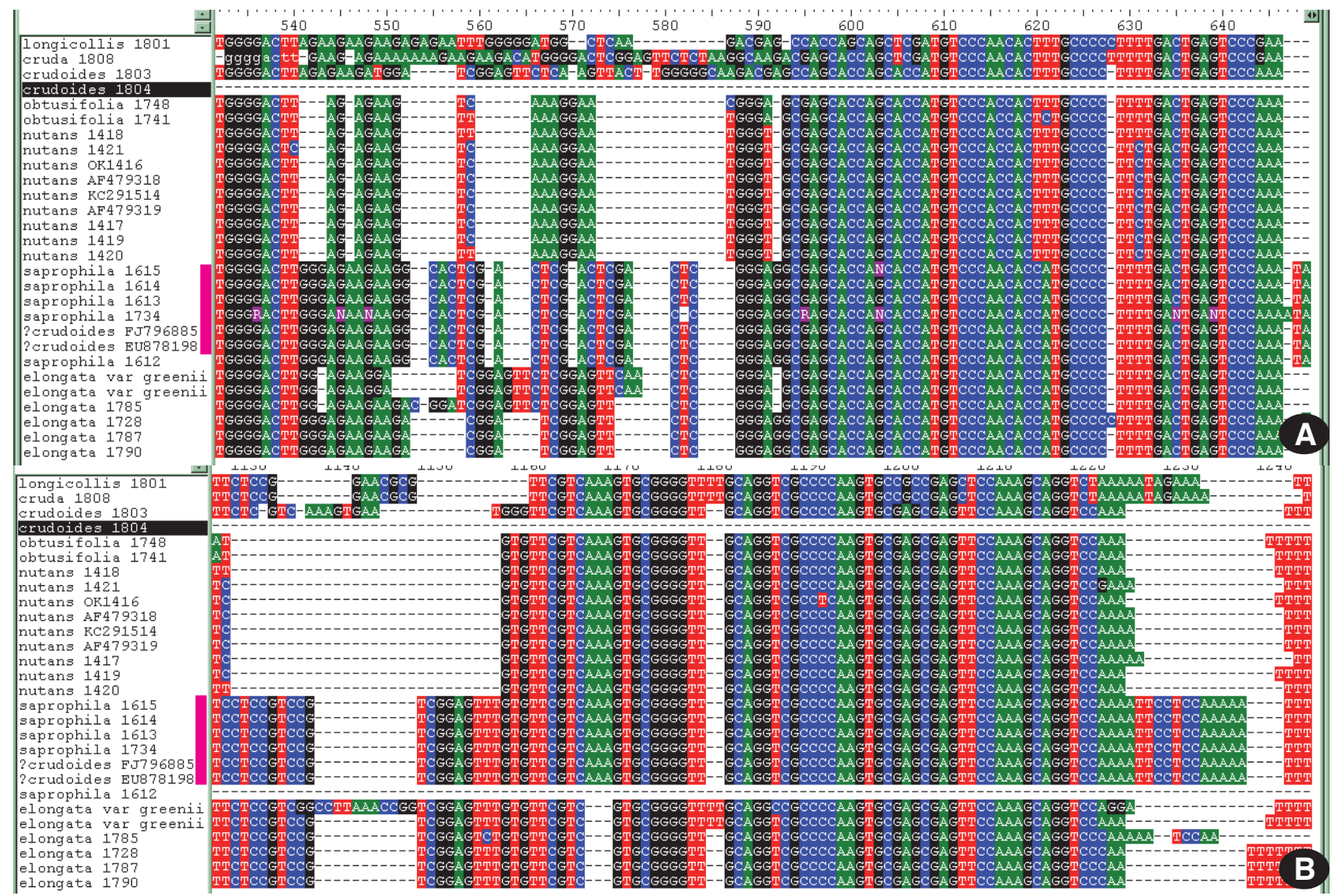

Fig. 1. Fragments of ITS alignment of Pohlia, showing unique motifs in ITS1 (A) and ITS2 (B) of Pohlia saprophila (marked by magenta vertical bar). Note two GenBank sequences labelled "P. crudoides" that are identical with P. saprophila and different from two speciemens of $P$. crudoides.

subapical part of the vegetative stems, 1-3 per axil, erect. Dioicous. Perichaetial leaves narrowly linear-lanceolate. Perigonia terminal, perigonial bracts acuminate. Setae $0.7-2(-3) \mathrm{cm}$, yellow to reddish-brown. Capsules inclined to horizontal, $2-3.5 \mathrm{~mm}$ long, $0.5-0.7 \mathrm{~mm}$ wide, narrowly cylindrical, yellow to brown when mature, slightly constricted below mouth when empty, neck 1/4$1 / 3$, rarely $1 / 2$ of capsule length; exothecial cells rectangular to elongate, with straight, thick walls, stomata superficial. Operculum conic, acute. Annulus of one cell row, revoluble. Exostome teeth yellow, acute-triangular, narrowly bordered, finely papillose proximally, coarsely papillose distally. Endostome hyaline, densely papillose, basal membrane low, segments keeled, narrowly perforate, cilia long, nodulose, rarely short. Spores light yellow, 12-15 $\mu \mathrm{m}$, finely papillose.

Differentiation. Pohlia saprophila is recognized by a compact tufts with dense rhizoids, narrowly cylindrical capsules in combination with dioicous sexual condition, long lanceolate, light green leaves with narrowly recurved margins and endostome with long cilia. Propaguliferous flagelliform branches often present on top of vegetative stems. The other species of the genus with narrowly cylindrical capsules from Asia are P. longicollis and P. elongata. Pohlia saprophila differs from them in compact tufts with dense rhizoids, dioicous sexual condition and long, nodulose cilia of endostome. Laminal cells in $P$. saprophila are rectangular to linear, thickwalled, unlike cells of $P$. elongata, which are thick-walled but short-rectangular, and unlike cells of $P$. longicollis, which are rectangular to linear but thin-walled. There are two Chinese species with narrowly cylindrical capsules, i.e., Pohlia macrocarpa D.-C. Zhang, X.-J. Li \& Higuchi and P. hyaloperistoma D.-C. Zang, X.-J. Li \& Higuchi (Zhang et al., 2007). Pohlia saprophila differ from them by compact tufts with dense rhizoids and long vs. absent cilia of endostome; furthermore, it differ from $P$. hyaloperistoma in dioicous vs. autoicous sexual condition, and from $P$. macrocarpa in recurved vs. plane leaf margins. Pohlia saprophila differs from dioicous $P$. sphagnicola in compact tufts with dense rhizoids, narrowly cylindrical capsules and ecology.

Middle Asian and Chinese plants of Pohlia saprophila differ from the South Siberian and Kamchatkan plants in somewhat longer setae and occasionally longer capsules, up to $6 \mathrm{~mm}$ (Savich-Lyubitskaya \& Smirnova, 1970). Flagelliform branches are more common in Kamchatkan plants, where they were seen on many shoots in most specimens, and occasionally two to three such branches occur on one shoot.

Distribution (Fig. 4). Pohlia saprophila is known from Kansu (Gansu), Xinjiang and Hebei Provinces of China (Müller, 1896; Zhao, 1993; herbarium specimens in LE). The species was reported from Mongolia (Abra- 
Fig. 2. Bayesian tree based on ITS analysis of Pohlia saprophila and related species of Pohlia. Posterior probabilities are above branches, and MP boorstrap support values are below branches. Support for small clades nested within terminal clades is not shown.

0.05 Saprophila Altai MG733042

99

saprophila Kamchatka MG733047

-"crudoides" China FJ796885

saprophila Kamchatka MG733045

[ saprophila Transbaikalia MG733046

saprophila Transbaikalia MG733044

saprophila Kamchatka MG733043

98 1. 00 elongata var. greenii Cacucasus MG733063

99 L elongata. var greeni Transbaikalia MG733064

$1.00 \quad$ elongata Kamchatka MG733050

100 elongata Amur MG733049

elongata middle West Siberia MG733048

Lelongata northern West Siberia MG733051

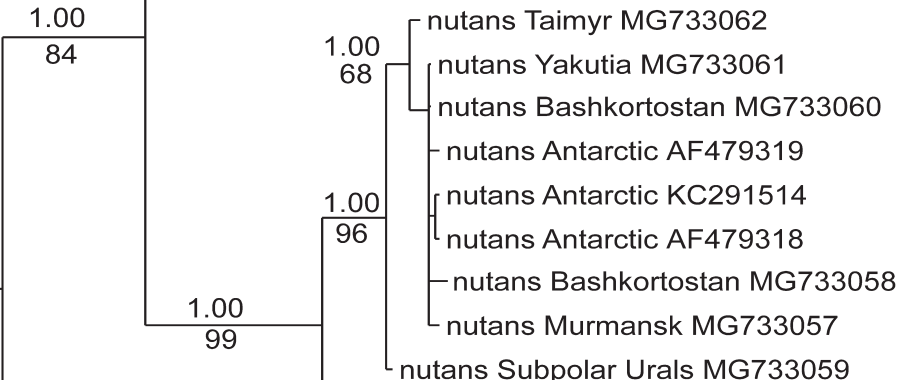

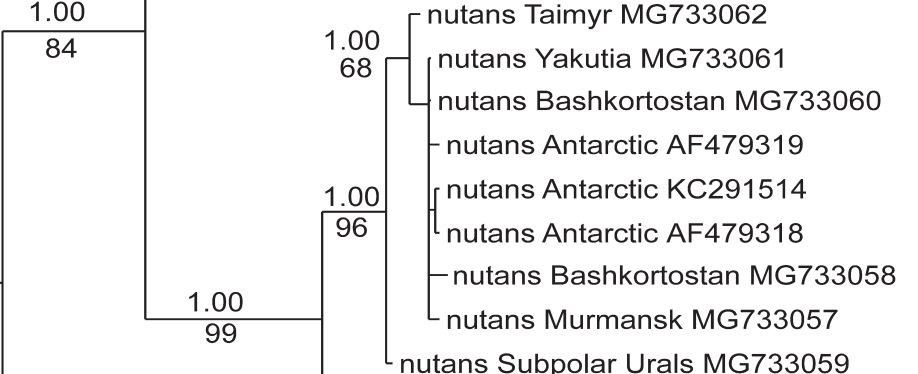

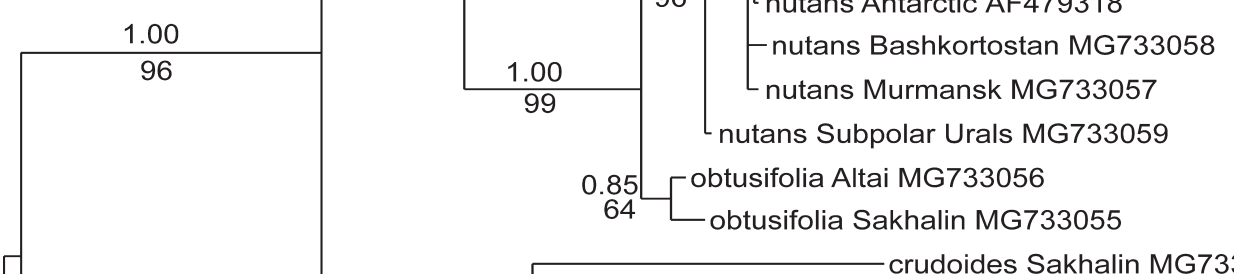

0.95 crudoides Sakhalin MG733066 Crudoides Kamchatka MG733065

crudoides Yakutia MG733053

crudoides Yakitia MG733052

1.00 cruda Yakitia MG733067

longicollis Khabarovsk MG733041

mova \& Tsegmed, 1979; Abramov \& Abramova, 1983) and Tsegmed (2010) cited it for five physiographic regions of Mongolia: Prikhubsugul, Khentei, Khangai, Khobdoss and Mongolian Altai, which cover most territory of the country. Savich-Lyunitskaya \& Smirnova (1970) reported P. saprophila for the Middle Asia within the former USSR, where it occurs in Kazakhstan and Kyrgyzstan (Ignatov et al., 2006; Eremina, 1965; Sakauova, 1992; Mamatkulov et al., 1998; specimens in LE). The species was also reported from NE European Russia (Zheleznova, 1994), but the specimen appeared to belong to P. longicollis. Then, it was collected in Altai and presented into database of Moss Flora of Russia (cf. Ivanov et al., 2017), but not published formally. Revising material for the Moss flora of Russia project, we found more localities of $P$. saprophila in southern Siberia and Kamchatka.

Ecology. Pohlia saprophila grows on rotten wood in spruce, birch and larch forests; rarely it is found at bases of trunks and on the bark of old trees. In Mongolia, this species was also collected on soil and rocks (Tsegmed, 2010). In Middle Asia, China, Mongolia and South Si- beria, Pohlia saprophila grows at 1100-3000 m a.s.1. In Kamchatka Territory, it occurs at alstitudes 500-900 m. Pohlia saprophila forms pure dense tufts or occasionally grows with minor admixture of Cynodontium asperifolium (Lindb. \& Arnell) Paris, Flexitrichum flexicaule (Schwägr.) Fedosov \& Ignatov, Pylaisia polyantha (Hedw.) Bruch, Schimp. \& W.Gümbel, Sanionia uncinata (Hedw.) Loeske, and Oncophorus spp.

Specimens examined: (specimens in LE, if not otherwise mentioned); $\mathrm{S}+-$ with capsule, $\mathrm{Pr}+-$ with propaguliferous flagelliform branches): CHINA: Xinjiang Province: Tianshan Mt., N slope, Da-niou, 17.VII.1957, Guan 1497, S+; Mt. Bogda, 19.VIII.1931, Liu, S+, P+. Hebei Province, Weichang, X.1899, Palibin, S+, Pr+. Gansu Province, Nanshan Range, vicinity Edzin-Gol River, valley Bardun River, $3000 \mathrm{~m}$ alt., 15.V.1886 and 17.V.1886 17.V.1886 23.V.1885, Potanin, S+: and 17.V.1886 23.V.1885, Potanin, S+. MONGOLIA: Prikhubsugul Province, circa lacus Ubsa, 16.VII.1879 and 17.VII.1879, Potanin, S+, Pr+. Khangai Province, Arakhangaiski Aimak, Taryat somon, $2135 \mathrm{~m}$ alt., 22.VI.1977, Tsegmed 3045, S+, Pr+. Khentei Province, vicinity Ulan-Bator, 10.IX.1974, Tsegmed 2417, Pr+. MIDDLE ASIA: Inter Turkestanicum, Kungei, Regel 3457, S+; Inter Turkestanicum, Borgasy, 5-6000' (=1830 m 


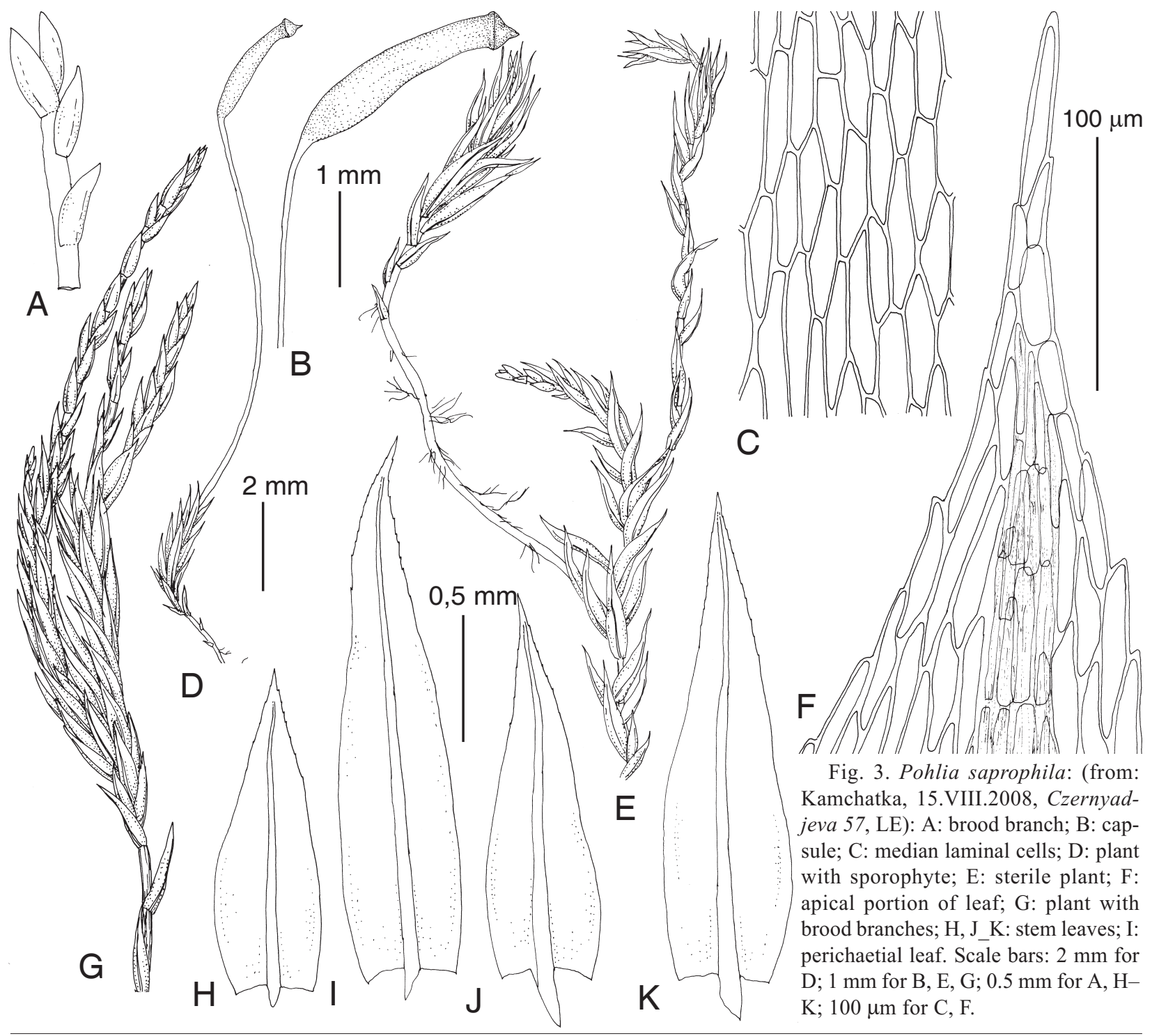

alt.), 4.VII.1879, Regel 3141, S+. KAZAKHSTAN: Almatinakaya Province: valley Levyi Talgar River, $\sim 2700 \mathrm{~m}$ alt., 1.IX.1958, Lisowski, S+; Ketmen' Range, 2800 m alt., 6.VIII.1946, Rubtsov 16, S+, Pr+. KIRGIZSTAN: Issukkul Lake, 9000' (=3130 m alt.), 19.VIII.1877, Regel 888, S+. RUSSUA:

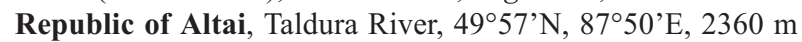
alt., 11.VII.2012, Ignatov \& Ignatova 12-382, S+. Republic of Buryatia, East Sayan, upper of Oka River, vicinity Orlik Settl., 52³0'N, 9950'E, 1412 m alt., 1.VII.2008, Afonina 00408, S+, Pr+. Zabaikalsky Territory: Sokhondinsky State Reserve:

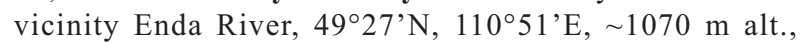
8.VII.2010, Czernyadjeva 2-10, $\mathrm{Pr}+$; vicinity Agutsa River, $49^{\circ} 40^{\prime} \mathrm{N}, 111^{\circ} 26^{\prime} \mathrm{E}, \sim 1100 \mathrm{~m}$ alt., 20.VII.2010, Czernyadjeva 33-10, Pr+. Kamchatka Territory: Shiveluch Volcano, $56^{\circ} 33^{\prime}$ N, $161^{\circ} 11^{\prime} \mathrm{E}, 514 \mathrm{~m}$ alt., 20.VII.2001, Czernyadjeva 24 , $25,26, \mathrm{~S}+, \mathrm{Pr}+$; Kluchevskaya group of volcano, vicinity of Kopyto Mt.: $55^{\circ} 57^{\prime} \mathrm{N}, 160^{\circ} 11^{\prime} \mathrm{E}, 660 \mathrm{~m}$ alt., 13.VIII.2004, $C z-$ ernyadjeva 69, $\mathrm{S}+, \mathrm{Pr}+$; $55^{\circ} 57^{\prime} \mathrm{N}, 160^{\circ} 14^{\prime} \mathrm{E}, 933 \mathrm{~m}$ alt., 13.VIII.2004, Czernyadjeva 71, S+, Pr+; Kluchevskaya group of volcano, Ostryy Tolbatchick Volcano: $55^{\circ} 46^{\prime} \mathrm{N}, 160^{\circ} 16^{\prime} \mathrm{E}$, $910 \mathrm{~m}$ alt., 16.VIII.2006, Czernyadjeva 961, S+, Pr+; 5546’ N, $160^{\circ} 13$ 'E, $880 \mathrm{~m}$ alt., 15.VIII.2008, Dulin 57, S+, Pr+.
Pohlia elongata Hedw., Sp. Musc. Frond. 171. 1801. Lectotype in BM (Shaw, 1982), not seen.

Pohlia viridis Lindb. \& Arnell, Kongl. Svenska Vetensk. Acad. Handl., n.s. 23(10): 55. 1890. syn. nov.

Lectotype S-B170418 (selected here): Partly printed label: "Pohlia viridis Lindb. et Arn., Sibiria: Jenisei, Antsiferove, 5910 n. lat., i [mycelklädd] klippspringa, 27/6/1876." On small envelope inside bigger envelope: "Aoter! Pohlia (n.sp.) viridis!, Sibiria: Jenisei, Antsiferovo, 59 n. lat., i híla i urberg, 27/6/1876”.

Notes on lectotypification: Stockholm herbarium possesses 3 syntypes, all from the same locality, Anziferova $59^{\circ} \mathrm{n}$. lat., and principally all of them could be chosen. We select the least problematic specmen, as two other ones have the followings disagreements with the protologue. The species is described as dioicous, while B170419 is annotated "polyoica!", and B170420 (from Herbarium Forstrer, Dr. Georg Roth. Herb. Hj. Möller) has less complete locality information.

We found paroicous plants in the lectotype, as well as in one of syntypes. Therefore we see no difference be- 


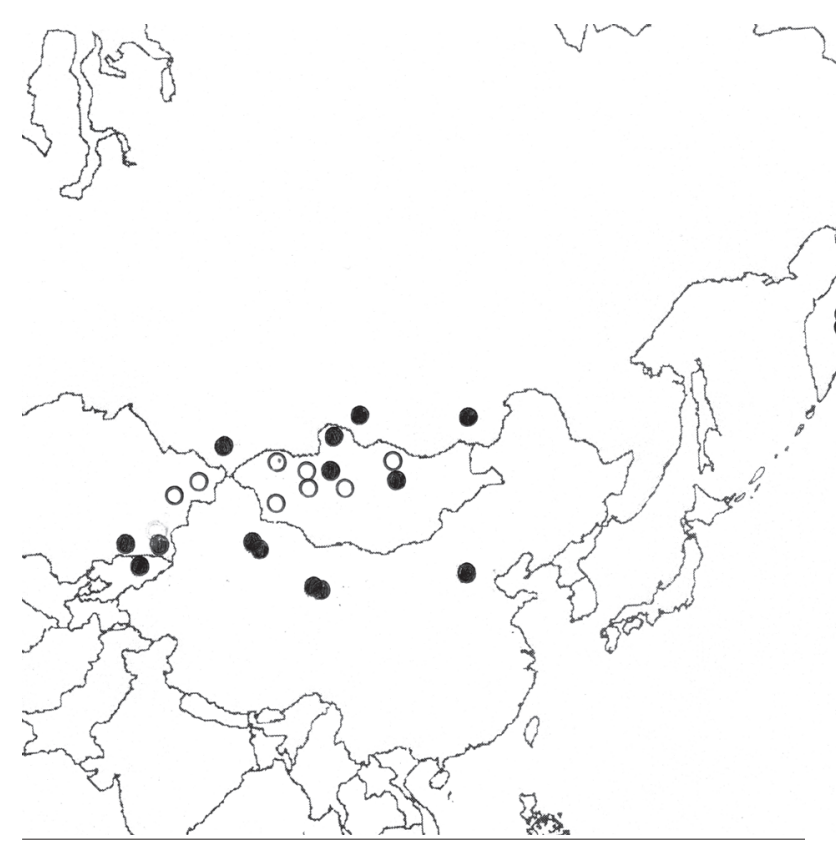

tween $P$. viridis and $P$. elongata sufficient for the taxonomic recognition of the former.

\section{ACKNOWLEDGEMENTS}

The work of I.V. Czernyadjeva was carried out within the framework of the institutional research project (no. 01201255616) of the Komarov Botanical Institute of the Russian Academy of Sciences and partially supported by RFBR (grant no. 16-04-01156).

\section{LITERATURE CITED}

[ABRAMOV, I.I. \& A.L. ABRAMOVA]. АБРАМОВ И.И., А.Л. АБРАМОВА. 1983. Конспект флоры мхов Монгольской народной республики. - [Konspekt flory mhov Mongolskoj Narodnoj Respubliki] Л., Наука [Leningrad, Nauka], 221 pp.

[ABRAMOVA, A.L. \& TS. TSEGMED] АБРАМОВА А.Л., Ц. ЦЭГМЭД. 1979. Редкие и интересные виды мхов Монголии. - [Rare and interesting mosses of Mongolia] Новости систематики низших растений [Novosti Sistematiki Nizshikh Rastenij] 16: 169-175.

BROTHERUS, V.F. 1903. Bryales. - In: H.G.A. Engler \& K. Prantl (eds.) Die Natürlichen Pflanzenfamilien. I(3). Leipzig, 481-576.

[EREMINA, N.KH.] EPЕМИНА Н.Х. 1965B. Материалы к флоре акрокарпных мхов Заилийского Алатау. - [Materials on flora of acrocarpous mosses of Zailiisky Alatau] Ботанические материаль Гербария института ботаники АН Каз ССР [Botanicheskie Materialy Herbaria Institita Botaniki Akademii Nauk Kazakhskoj SSR] 3: $115-125$.

GARDINER, A., M. IGNATOV, S. HUTTUNEN \& A. TROITSKY. 2005. On resurrection of the families Pseudoleskeaceae Schimp. and Pylaisiaceae Schimp. (Musci, Hypnales). - Taxon 54: 651-663.

GOLOBOFF, P.A. 1994. NONA: A Tree Searching Program.-Program and documentation, published by the author, Tucumán, Argentina.

HALL, T.A. 1999. BioEdit: a user-friendly biological sequence alignment editor and analysis program for Windows 95/98/NT. - Nucleic Acids Symposium Series 41: 95-98.

IGNATOV, M.S., O.M. AFONINA, E.A. IGNATOVA, A. ABOLINA, T.V. AKATOVA, E.Z. BAISHEVA, L.V. BARDUNOV, E.A. BARYAKINA, O.A. BELKINA, A.G. BEZGODOV, M.A.BOYCHUK, V.YA. CHERDANTSEVA, I.V. CZERNYADJEVA, G.YA. DOROSHINA, A.P. DYACHENKO, V.E. FEDOSOV, I.L. GOLDBERG, E.I. IVANOVA, I. JUKONIENE, L. KANNUKENE, S.G.KAZANOVSKY, Z.KH.
Fig. 4. Distribution of Pohlia saprophila. Solid circles - specimens examined from herbarium collections; hollow circles - literature data.

KHARZINOV, L.E. KURBATOVA, A.I. MAKSIMOV, U.K. MAMATKULOV, V.A. MANAKYAN, O.M. MASLOVSKY, M.G. NAPREENKO, T.N. OTNYUKOVA, L.YA. PARTYKA, O.YU. PISARENKO, N.N. POPOVA, G.F. RYKOVSKY, D.YA. TUBANOVA, G.V. ZHELEZNOVA \& V.I. ZOLOTOV. 2006. Check-list of mosses of East Europe and North Asia. - Arctoa 15: 1-130.

IVANOV, O.V., M.A. KOLESNIKOVA, O.M. AFONINA, T.V. AKATOVA, E.Z. BAISHEVA, O.A. BELKINA, A.G. BEZGODOV, I.V. CZERNYADJEVA, S.V. DUDOV, V.E. FEDOSOV, E.A. IGNATOVA, E.I. IVANOVA, M.N. KOZHIN, E.D. LAPSHINA, A.A. NOTOV, O.YU. PISARENKO, N.N. POPOVA, A.N. SAVCHENKO, V.V. TELEGANOVA, G.YA. UKRAINSKAYA \& M.S. IGNATOV. 2017. The database of the Moss Flora of Russia. - Arctoa 26(1): 1-10.

[MAMATKULOV, U.K., I.O. BAITULIN \& S.G. NESTEROVA] МАМАТКУЛОВ У.К., И.О. БАЙТУЛИН, С.Г. НЕСТЕРОВА. 1998. Мохообразные Средней Азии и Казахстана. - [Bryophytes of the Middle Asia and Kazakhstan] Алматы [Almaty], 232 pp.

MÜLLER, C. 1896. Bryologia provinciae Schensi sinensis I. - Nuovo giornale botanico italiano, n.s. 3: 89-129.

REDFEARN, P.L., B.C. TAN \& S. HE. 1996. A newly updated and annotated checklist of Chinese mosses. - Journal of the Hattori Botanical Laboratory 79: 163-357.

RONQUIST, F., M. TESLENKO, P. VAN DER MARK, D.L. AYRES, A. DARLING, S. HÖHNA, B. LARGET, L. LIU, M.A. SUCHARD \& J.P. HUELSENBECK. 2012. MrBayes 3.2: Efficient Bayesian phylogenetic inference and model choice across a large model space. - Systematic Biology 61: 539-542.

[SAKAUOVA, G.B.] САКАУОВА Г.Б. 1992. Мохообразные Южного Алтая. - [Bryophytes of South Altai] Автореф. дисс... канд. биол. наук Душанбе, АН Респ. Таджикистан, Инст. Бот. [Thesis Ph. D.. Dushanbe, Akad. Nauk. Resp. Tadjikistan, Inst. Bot.], 22 p.

[SAVICZ-LYUBITSKAYA, L.I. \& Z.N. SMIRNOVA] САВИЧЛЮБИЦКАЯ Л.И., З.Н. СМИРНОВА 1970. Определитель листостебельных мхов СССР. Верхоплодные мхи. - [Handbook of mosses of the USSR. The acrocarpous mosses] Л., Наука [Leningrad, Nau$k a], 822$.

SHAW, J. 1982. Pohlia Hedw. (Musci) in North and Central America and the West Indies. - Contributions from the University of Michigan Herbarium 15: 219-295.

SHAW, J. 2014. Mielichhoferiaceae. - In: Flora of North America Editorial Committee (eds.) Flora of North America North of Mexico 28 : 189-214.

[TSEGMED, TS.] ЦЭГМЭД Ц. 2010. Флора мхов Монголии. - [Moss flora of Mongolia] M. Труды совместной российско-монгольской комплексной биологической экспедиции [Moscow, Trudy Sovmestnoi Rossiisko-Mongolskoi Kompleksnoi Biologicheskoi Ekspeditsii], $635 \mathrm{pp}$.

[ZHELEZNOVA, G.V.] ЖЕЛЕЗНОВА Г.В. 1994. Флора листостебельных мхов Европейского Северо-Востока. - [Moss flora of European North-East] СПб., Наука [St.- Petersburg, Nauka], 148 pp.

ZHANG, D., X. LI \& S. HE. 2007. Bryaceae. - In: Moss Flora of China. English Version. Vol. 4. Beijing, New York and St.-Louis, Science Press and Missouri Botanical Garden: 3-92.

ZHAO, J.-C. 1993. A preliminary study on the bryophytes of eastern section of Tianshan Mountains, Northwest China. - Chenia 1: 99-112. 